\title{
NILE TILAPIA FED ENZYME COMPLEX ADDED AT DIFFERENT LEVELS AND PROCESSING STEPS ${ }^{1}$
}

\author{
MARCELO GASPARY MARTINS ${ }^{2 *}$, GUILHERME DE SOUZA MOURA ${ }^{3}$, ANDRE LIMA FERREIRA ${ }^{2}$, MARCELO \\ MATTOS PEDREIRA ${ }^{2}$, EDUARDO ARRUDA TEIXEIRA LANNA ${ }^{4}$
}

\begin{abstract}
Enzyme activity in solid-state fermentation complex added to diets before and after extrusion process and its influence on Nile tilapia (Oreochromis niloticus) performance were evaluated. The following enzymes were analyzed: b-glucosidase, pectinase, xylanase, endoglucanase, amylase, protease, and phytase. The fish were fed five experimental diets: a control diet (without enzyme), two test diets supplemented before extrusion (400 and 800 ppm SSF), and two test diets after extrusion or "on top" (400 and 800 ppm SSF). The experiment had a completely randomized design with four replicates and seven fish per tank. Average initial weight was $10.37 \pm 0.95 \mathrm{~g}$, and fish were fed four times a day to satiation for 56 days. The following performance parameters were evaluated: final weight, weight gain, feed conversion, survival, specific growth rate, and body composition. The results were compared using ANOVA and Tukey's test at $\mathrm{p}<0.05$. All the enzymes showed partial or total losses of activity when subjected to the extrusion process, except phytase. No differences were observed for survival, water quality parameters, and body composition. On-top inclusion provided a better performance, which is observed through increases in final weight, weight gain, and feed conversion. As a result, 800 ppm of enzyme complex SSF should be added "on top", that is after extrusion, to improve tilapia performance and, consequently, contribute to the fish farming financial efficiency.
\end{abstract}

Keywords: Solid-state fermentation. Fish nutrition. Animal production.

\section{TILÁPIA DO NILO ALIMENTADA COM COMPLEXO ENZIMÁTICO ADICIONADO EM DIFERENTES NÍVEIS E ETAPAS DO PROCESSAMENTO}

RESUMO - As atividades das enzimas do complexo enzimático SSF (solid-state fermentation) adicionado à ração antes e após o processo de extrusão e a influência no desempenho de tilápias do Nilo (Oreochromis niloticus) foram avaliadas. Foram selecionadas as seguintes enzimas para análise: b-glicosidase, pectinase, xilanase, endoglucanase, amilase, protease e fitase. Os peixes foram submetidos a cinco tratamentos: ração sem adição de enzima, com adição de 400 ppm de SSF antes da extrusão, com 800 ppm de SSF antes da extrusão, 400 ppm de SSF adicionados “on top” após a extrusão e 800 ppm de SSF adicionados “on top” após a extrusão. O experimento teve um delineamento inteiramente casualizado com quatro repetições, contendo sete peixes por aquário. O peso médio inicial foi de $10,37 \mathrm{~g} \pm 0,95$, sendo alimentados quatro vezes ao dia, até a saciedade, durante 56 dias. Avaliou-se: peso inicial, peso final, ganho de peso, conversão alimentar, sobrevivência, taxa de crescimento específico e composição corporal. Os resultados foram comparados utilizando-se ANOVA e teste de Tukey a $\mathrm{p}<0.05$. Todas as enzimas perderam atividade enzimática parcial ou total quando submetidas ao processo de extrusão, exceto a fitase. Não foram observadas diferenças entre a sobrevivência, parâmetros de qualidade da água e a composição corporal. A inclusão “on top" proporcionou um melhor rendimento, observado através de melhorias no peso final, ganho de peso e conversão alimentar. Concluiu-se que, $800 \mathrm{ppm}$ de SSF deve ser adicionado "on top", após a extrusão, para proporcionar um melhor desempenho em tilápias, e consequentemente a eficiência financeira da produção.

Palavras-chave: Fermentação em estado sólido. Nutrição de peixes. Produção Animal.

\footnotetext{
${ }^{*}$ Corresponding author

${ }^{1}$ Received for publication in $04 / 20 / 2016$; accepted in $03 / 15 / 2017$.

Extracted from the first author's Masters dissertation.

${ }^{2}$ Universidade Federal dos Vales do Jequitinhonha e Mucuri, Diamantina, MG, Brazil; marcelogaspary@gmail.com, andrelima_3m@hotmail.com, marcelomattospedreira@gmail.com.

${ }^{3}$ Instituto Federal do Sudeste de Minas Gerais, Rio Pomba, MG, Brazil; mouraguilherme@yahoo.com.br.

${ }^{4}$ Universidade Federal de Viçosa, Viçosa, MG, Brazil; eduardoalanna@yahoo.com.br.
} 


\section{INTRODUCTION}

Tilapia has many favorable characteristics for fish farming purposes such as hardiness and ease of management. It is highly prolific, productive and its artificial reproduction has been consolidated, making it possible to produce fingerlings all year (ELSAYED, 2006). Also according to the same author, this fish is able to adapt itself to different production systems, diets, as well as feed plankton available on the medium; it also has meat with excellent nutritional qualities and high market value.

Aquaculture has stood out worldwide as a food production system, encouraging culturists and researchers to seek techniques capable of improving profits and productivity. Thus, food additives may be considered quite promising because, according to Campestrini, Silva and Appet (2005), they are intended to preserve, enhance, or modify the food properties without affecting its nutritional value.

Among the alternatives, enzymes can be considered one of the most promising candidates since they enhance the availability of nutrients and energy, resulting in a better performance and reduced waste (JEGANNATHAN; NIELSEN, 2013). Just as occurs with other monogastric animals, fish are unable to metabolize several nutrients due to insufficient production or absence of specific enzymes (TANIGUCHI; TAKANO, 2004), which justifies its inclusion in diets.

During the degradation of a substrate, various enzymes may act concertedly for an efficient digestion. As in the case of the enzyme complex SSF (solid-state fermentation), some enzymes are combined naturally and evenly, such as bglucosidase, pectinase, xylanase, endoglucanase, amylase, protease, and phytase (CHAUYNARONG et al., 2008).

The activity of enzymes added to animal diets can be affected by several factors such as chemicals, $\mathrm{pH}$ and mainly by temperature variations (CARLSON; POULSEN, 2003). In fish farming, extruded diets are widely used; such diets are developed through a process involving high temperatures. Thus, in this case, enzymes should be supplemented carefully because, due to the protein composition, partial or total loss of biological activity might occur.

Therefore, the stability of enzymes (complex SSF) during the extrusion process steps and subsequent effects on Nile tilapia (Oreochromis niloticus) performance were evaluated in this study.

\section{MATERIAL AND METHODS}

This study was conducted from May to July 2014, under the authorization of the local ethics council. The basal diet was prepared in a feed mill and extruder, using ingredients of vegetable origin. The used enzyme complex Allzyme SSF, supplied by Alltech Inc. (Nicholasville, Kentucky, USA), contains the enzymes $\beta$-glucosidase, pectinase, xylanase, endoglucanase, amylase, protease, and phytase.

For the assay of enzyme activity, the basal feed (Table 1) was used in all treatments, differing only in the steps and inclusion levels. Treatments consisted of substituting supplementation with SSD from 4 to $8 \%$ of the basal diet, as follows: control (without enzyme), 4000 ppm SSF before extrusion (BE4), 8000 ppm SSF before extrusion (BE8), 4000 SSF after extrusion (AE4), and 8000 SSF after extrusion (AE4). SSF inclusion levels, before and after, were ten times higher than were those used for performance tests. These higher levels are justified by the difficulty in extracting enzymes and quantifying their activity through the currently used methods (ESMAEILIPOUR et al., 2012).

All treatments had jelly in their composition in order to prevent any kind of influence on ingredient basis, differing only at the time of inclusion.

In the treatments with enzymes added before extruded process and control (no enzyme), the jelly was incorporated into the mixture and only differing as regards the SSF inclusion level $(0,4000$, and 8000 $\mathrm{ppm})$. Yet for treatments with enzyme inclusion after extrusion process (4000 and $8000 \mathrm{ppm}$ ), the jelly was prepared and mixed with the enzyme complex, so being built "on top". All diets were processed with an extruder machine (Inbramaq, MX40), being produced pellet with an average diameter of $2 \mathrm{~mm}$ at $90{ }^{\circ} \mathrm{C}$ with subsequent drying. Finally, the samples were ground and separated for enzymatic analysis.

\section{First Trial}

For determination of enzyme activities, a 0.5 -g sample of each diet was macerated with $10 \mathrm{~mL}$ distilled water. This material was placed into polyethylene tubes to be centrifuged at $13000 \mathrm{rpm}$ for 10 minutes. Afterwards, the supernatant was pipetted off for enzyme activity determination. All enzymatic analyzes were performed in triplicate. The following enzymes, present in the complex included to the feed, were selected for analysis: b-glycosidase, pectinase, xylanase, endoglucanase (carboxymethyl cellulase), amylase, protease, and phytase. 
Table 1. Composition of experimental diets (natural matter).

\begin{tabular}{|c|c|c|c|}
\hline \multirow[t]{2}{*}{ Ingredients $(\%)$} & \multicolumn{3}{|c|}{ Treatments } \\
\hline & Control & BE4 and AE4 & BE8 and AE8 \\
\hline Soybean meal & 71.88 & 71.88 & 71.88 \\
\hline Corn & 20.12 & 20.12 & 20.12 \\
\hline Wheat bran & 3.00 & 3.00 & 3.00 \\
\hline Dicalcium phosphate & 2.83 & 2.83 & 2.83 \\
\hline Limestone & 0.76 & 0.76 & 0.76 \\
\hline Soybean oil & 0.20 & 0.20 & 0.20 \\
\hline Vitamin and Mineral supplement ${ }^{(1)}$ & 0.50 & 0.50 & 0.50 \\
\hline Vitamin C & 0.05 & 0.05 & 0.05 \\
\hline Salt & 0.50 & 0.50 & 0.50 \\
\hline Inert* & 0.08 & 0.04 & - \\
\hline $\mathrm{SSF}^{(2)}$ & - & 0.04 & 0.08 \\
\hline Jelly ${ }^{(4)}$ & 0.06 & 0.06 & 0.06 \\
\hline $\mathrm{BHT}^{(3)}$ & 0.02 & 0.02 & 0.02 \\
\hline \multicolumn{4}{|c|}{ Calculated $^{(5)}$ and analyzed ${ }^{(6)}$ composition } \\
\hline Dry matter ${ }^{(6)}$ & 87.38 & 87.45 & 87.24 \\
\hline Crude protein ${ }^{(6)}$ & 33.31 & 34.02 & 34.05 \\
\hline Mineral matter ${ }^{(6)}$ & 5.99 & 6.04 & 6.06 \\
\hline Digestible energy $(\mathrm{kcal} / \mathrm{kg})^{(5)}$ & 3000 & 3000 & 3000 \\
\hline Crude fiber ${ }^{(5)}$ & 4.92 & 4.92 & 4.92 \\
\hline Ether extract ${ }^{(6)}$ & 1.69 & 1.87 & 1.71 \\
\hline Total calcium ${ }^{(6)}$ & 1.12 & 1.09 & 1.10 \\
\hline Total phosphorus ${ }^{(6)}$ & 1.71 & 1.65 & 1.69 \\
\hline Total lysine ${ }^{(5)}$ & 2.07 & 2.07 & 2.07 \\
\hline Linoleic acid $^{(5)}$ & 1.06 & 1.06 & 1.06 \\
\hline
\end{tabular}

*Ingredient without nutritional value ${ }^{(1)}$ Composition per $\mathrm{kg}$ of product: 1,200,000 IU Vitamin A; 200,000 IU Vitamin $\mathrm{D}_{3} ; 1,200 \mathrm{mg}$ Vitamin $\mathrm{E} ; 2,400 \mathrm{mg}$ Vitamin $\mathrm{K}_{3} ; 4,800 \mathrm{mg}$ Vitamin $\mathrm{B}_{1} ; 4,800 \mathrm{mg}$ Vitamin $\mathrm{B}_{2}$; 4,800 mg Vitamin $\mathrm{B}_{6} ; 4,800 \mathrm{mg}$ Vitamin $\mathrm{B}_{12} ; 48 \mathrm{~g}$ Vitamin $\mathrm{C} ; 1200 \mathrm{mg}$ folic acid; 12,000 mg pantothenic acid; $48 \mathrm{mg}$ biotin; $108 \mathrm{~g}$ choline chloride; 24,000 mg niacin; 50,000 mg Fe; 3,000 mg Cu; 20,000 mg Mn; 30,000 mg Zn; $100 \mathrm{mg} \mathrm{I} ; 10 \mathrm{mg} \mathrm{Co} ; 100 \mathrm{mg}$ Se. ${ }^{(2)}$ Allzyme SSF, Alltech Inc. ${ }^{(3)}$ Values based on the coefficient of digestibility of ingredients.

The $\beta$-glucosidase is an exocellulase with specificity for a variety of substrates. This enzyme hydrolyzes the non-reducing end of $\beta$-glycosides, releasing glucose. In this assay, we used $100 \mu \mathrm{L}$ enzyme extract, $100 \mu \mathrm{L}$ sodium acetate buffer (100 mM, pH 5), and $250 \mu \mathrm{L}$ solution of $2 \mathrm{mM}$ synthetic substrate. The reaction was conducted for 15 minutes at $50{ }^{\circ} \mathrm{C}$ and paralyzed with $500-\mu \mathrm{L}$ sodium carbonate $(0.5 \mathrm{M})$. Then, the solution was taken to a spectrophotometer for absorbance reading at $410 \mathrm{~nm}$ and, thus, determination of enzyme activity.

For pectinase, we used $25 \mu \mathrm{L}$ enzyme extract, $75 \mu \mathrm{L}$ sodium acetate buffer $(100 \mathrm{mM}, \mathrm{pH} 5)$, and $400 \mu \mathrm{L}$ galacturonic acid solution $(0.25 \% \mathrm{w} / \mathrm{v})$. The reaction was conducted for 30 minutes at $50{ }^{\circ} \mathrm{C}$ and paralyzed with $500 \mu \mathrm{L}$ DNS reagent (3,5 dinitrosalicylic acid) and thereafter incubated in boiling water bath for 5 minutes for color development. After, the solutions were centrifuged in polyethylene tubes at 13,000 rpm for 5 minutes. The solution was taken to the spectrophotometer for absorbance reading at $540 \mathrm{~nm}$ and, then, determination of enzyme activity.

The xylanase activity was determined using $80-\mu \mathrm{L}$ sodium acetate buffer (100 mM, pH 5), $20 \mu \mathrm{L}$ enzyme extract, and $400-\mu \mathrm{L}$ Birch wood xylan solution $(1.25 \% \mathrm{w} / \mathrm{v})$. The reaction was conducted for 15 minutes at $50{ }^{\circ} \mathrm{C}$ paralyzed with $500 \mu \mathrm{L}$ DNS and then incubated in boiling water bath for 5 minutes for color development. The solution was taken to the spectrophotometer for absorbance reading at $540 \mathrm{~nm}$ and enzyme activity determination.

For endoglucanase (carboxymethyl cellulase), $25 \mu \mathrm{L}$ enzyme solution was mixed with $400 \mu \mathrm{L}$ carboxymethyl cellulose (CMC) $(1.25 \% \mathrm{w} / \mathrm{v})$, being diluted in $75 \mu \mathrm{L}$ sodium acetate buffer $(100 \mathrm{mM}$, $\mathrm{pH} 5)$. This solution was placed in a water bath at $50{ }^{\circ} \mathrm{C}$ for 30 minutes and after, the reaction was paralyzed with $500 \mu \mathrm{L}$ DNS according to Miller (1956). These solutions were placed in boiling water for 5 minutes and subsequently read for absorbance at $540 \mathrm{~nm}$ in the spectrophotometer, for enzyme activity assessment.

The $\alpha$-amylase activity was based on the releasing of maltose and dextrin molecules during hydrolysis of starch. By adding iodine, the non-hydrolyzed starch acquired a blue color. The amylase activity is inversely proportional to the blue color intensity, being calculated by comparison with a standard sample (control). The optical activity was determined in a spectrophotometer at a 660-nm wavelength, using the Bioclin colorimetric amylase 
kit according to Caraway (1959).

Regarding protease activity, $150-\mu \mathrm{L}$ azocasein $(2 \%)$ was incubated at $37{ }^{\circ} \mathrm{C}$ with $125-\mu \mathrm{L}$ enzyme extract for 30 minutes. Afterwards, $600 \mu \mathrm{L}$ TCA $(10 \%$ trichloroacetic acid) was added to the mixture, being allowed to stand for 15 minutes in an ice bath. Thereafter, the mixture was centrifuged for five minutes at $14,000 \mathrm{rpm}$, with the supernatant separated. An aliquot of the supernatant $(600 \mu \mathrm{L})$ was transferred to a tube containing $700 \mu \mathrm{L} 0.1 \mathrm{M}$ $\mathrm{NaOH}$ for absorbance reading at $440 \mathrm{~nm}$ in the spectrophotometer. Then, the protease activity was determined.

For phytase activity, the amount of inorganic phosphate released was measured from sodium phytate substrate. We used $600-\mu \mathrm{L}$ sodium phytate substrate $(1.5 \mathrm{mM})$ in $100 \mathrm{mM}$ sodium acetate buffer $(\mathrm{pH}$ 5.0) and $150-\mu \mathrm{L}$ enzyme extract. During 30 minutes, the mixture was conducted in a water bath at $50{ }^{\circ} \mathrm{C}$, being the reaction stopped by the addition of $250-\mu \mathrm{L}$ trichloroacetic acid $10 \%(\mathrm{v} / \mathrm{v})$. Afterwards, $1000 \mu \mathrm{L}$ colorimetric reagent was added to the assay tubes. This reagent was prepared from $10 \%$ ammonium molybdate solution $(\mathrm{w} / \mathrm{v})$ in $5 \mathrm{M}$ sulfuric acid solution. The reagent was prepared at the time of use, blending $10 \%(\mathrm{v} / \mathrm{v})$ from colorimetric reagent, $5 \%$ ferrous sulfate $(\mathrm{w} / \mathrm{v})$, and deionized water. Subsequently, the absorbance readings were carried out in a spectrophotometer at $700 \mathrm{~nm}$, correlating the values with a standard curve from $\mathrm{KH}_{2} \mathrm{PO}_{4}$.

\section{Second Trial}

The second trial consisted of an animal performance evaluation. It was conducted at the Laboratory of Aquaculture and Aquatic Ecology, Federal University of Vales do Jequitinhonha and Mucuri (UFVJM), in Diamantina - MG, Brazil. The study was carried out in 2013, for eight weeks (56 days), using Nile tilapia provided by CODEVASF (Janaúba - MG, Brazil). Two hundred Nile tilapia juveniles, GIFT strain, sexually reversed, with average initial weight of $10.37 \pm 0.38 \mathrm{~g}$, were used in the trial. In the beginning, initial weight and biomass $(\mathrm{g})$ were measured for each treatment. Fish were distributed in twenty $35-\mathrm{L}$ tanks, being 7 fish.tank ${ }^{-1}$, and 0.20 fish. $\mathrm{L}^{-1}$, with recirculation system containing an ultraviolet (UV) filter, being under constant aeration, temperature control, natural photoperiod, and bio-filtration conditions. The tanks were cleaned three times a week by siphoning, renewing $30 \%$ of the tank volume.

The juveniles were subjected to five diets (treatments): without enzyme (control), addition of 400 and 800 ppm SSF before extrusion (BE400 and BE800), addition of 400 and 800 ppm SSF after extrusion (AE400 and AE800), being distributed in a completely randomized design with four replicates of 7 fish.

A diet based on vegetable ingredients was adopted with the same initial composition as the one used in the enzyme assay, according to the formulation shown in Table 1. The fish were fed ad libitum (until satiation) four times daily (8 am, $11 \mathrm{am}, 2 \mathrm{pm}$, and $5 \mathrm{pm}$ ).

Once a week, water quality parameters were measured as follows: temperature, $\mathrm{pH}$, conductivity, dissolved oxygen (YSI Pro Plus multi-parameter probe) and ammonia (indophenol blue method) (APHA, 2012). The amount of offered and remained feed was daily measured using a precision scale $(0.01 \mathrm{~g})$ and subjected to estimate feed conversion ratio.

After 56 days of trial, in the only biometric experiment after the initial, all tilapia remained $12 \mathrm{~h}$ without food for the emptying of the digestive tract and body composition analysis, being captured and immersed in water plus eugenol $\left(37.5 \mathrm{mg} . \mathrm{L}^{-1}\right)$ about 30 minutes for euthanasia and weighing. In this point, we evaluated: survival (\%), final biomass ( $\mathrm{g}$ ), biomass gain $(\mathrm{g})$, final weight $(\mathrm{g})$, weight gain $(\mathrm{g})$, feed conversion (g. $\left.\mathrm{g}^{-1}\right)$, and specific growth rate - SGR $\left(\%\right.$.day $\left.{ }^{-1}\right)$.

The carcasses were dried in forced-hot air ovens and taken to the Laboratory of Animal Nutrition, Department of Animal Science (DZO), in UFVJM. Body composition parameters as dry matter $(\mathrm{DM})$, mineral matter $(\mathrm{MM})$, crude protein $(\mathrm{CP})$, ether extract $(\mathrm{EE})$, calcium $(\mathrm{Ca})$, and phosphorus $(\mathrm{P})$ were evaluated according to the methods described by Van Soest et al. (1991).

Data of enzyme activity and performance underwent analysis of variance (ANOVA) at 0.05 probability. The means were compared by the Tukey's test using the Statistical Analysis System software (SAS). Survival data were transformed to arcsine values but the Table shows them in percentage. For water quality parameters, means and standard deviations were calculated to characterize the rearing environment.

\section{RESULTS AND DISCUSSION}

The SSF inclusion into the Tilapia feed before extrusion resulted in the partial or total loss of enzyme activity, except for phytase, which had no influence from process temperature. Treatments showed significant differences $(\mathrm{p}<0.05)$ for b-glucosidase, amylase, and protease in function of treatments, with a partial loss of activity in the extrusion process.

A significant difference $(\mathrm{p}<0.05)$ was observed for pectinase xylanase and endoglucanase regarding the tested levels. The activities of these 
enzymes were totally lost during processing and there was no difference compared to control (Table 2).

The inclusion of 8000 ppm SSF after extrusion enhanced enzyme activity if compared to those of before-extrusion and control. The supplementation of 8000 ppm SSF before extrusion showed similar behavior as the $4000 \mathrm{ppm}$ after extrusion, which had no difference with the highest inclusion dose after extrusion.

Table 2. Enzyme activity of the SSF enzyme complex added at different levels and extrusion process steps for Nile tilapia diets.

\begin{tabular}{lcccccc}
\hline & \multicolumn{5}{c}{ Treatments } & \multirow{2}{*}{ CV (\%) } \\
\cline { 2 - 5 } Enzymes & Control & BE4 & BE8 & AE4 & AE4 \\
\cline { 2 - 5 } & 0.17 & 80.00 & 144.00 & 264.00 & 680.00 & 6.93 \\
$n^{*}$-glucosidase $^{1,2}$ & $\pm 0.01 \mathrm{e}$ & $\pm 1.20 \mathrm{~d}$ & $\pm 32.00 \mathrm{c}$ & $\pm 8.00 \mathrm{~b}$ & $\pm 8.00 \mathrm{a}$ & \\
Pectinase $^{1,2}$ & 0.69 & 0.36 & 0.58 & 11264.36 & 13127.41 & 5.45 \\
& $\pm 0.06 \mathrm{c}$ & $\pm 0.03 \mathrm{c}$ & $\pm 0.02 \mathrm{c}$ & $\pm 282.40 \mathrm{~b}$ & $\pm 416.30 \mathrm{a}$ & \\
Xylanase $^{1,2}$ & 0.63 & 0.75 & 0.49 & 168.21 & 216.30 & 22.82 \\
& $\pm 0.23 \mathrm{c}$ & $\pm 0.24 \mathrm{c}$ & $\pm 0.03 \mathrm{c}$ & $\pm 14.25 \mathrm{~b}$ & $\pm 14.44 \mathrm{a}$ & \\
Endoglucanase $^{1,2}$ & 0.49 & 0.44 & 0.41 & 255.88 & 316.11 & 6.13 \\
& $\pm 0.07 \mathrm{c}$ & $\pm 0.18 \mathrm{c}$ & $\pm 0.06 \mathrm{c}$ & $\pm 102.35 \mathrm{~b}$ & $\pm 126.84 \mathrm{a}$ & \\
Amylase $^{1,3}$ & 9.48 & 77.90 & 128.43 & 145.97 & 252.64 & 11.98 \\
& $\pm 7.44 \mathrm{~d}$ & $\pm 5.95 \mathrm{c}$ & $\pm 20.84 \mathrm{~b}$ & $\pm 23.18 \mathrm{~b}$ & $\pm 11.90 \mathrm{a}$ & \\
Protease $^{1,2}$ & 907.42 & 915.37 & 997.58 & 1123.02 & 1236.15 & 4.50 \\
& $\pm 0.10 \mathrm{c}$ & $\pm 0.02 \mathrm{c}$ & $\pm 0.01 \mathrm{bc}$ & $\pm 0.02 \mathrm{ab}$ & $\pm 0.01 \mathrm{a}$ & \\
Phytase $^{1,4}$ & 0.8162 & 313.33 & 594.33 & 327.33 & 608.33 & 3.54 \\
\hline
\end{tabular}

${ }^{1}$ Means following by the same letter are similar by the Tukey's test $(p<0.05) .{ }^{2}$ IU $_{\text {. }}{ }^{-1}$ (International unit.gram $\left.{ }^{-1}\right){ }^{3} \mathrm{AU} . \mathrm{g}^{-1}$ $\left(\right.$ Amylase unit.gram $\left.{ }^{-1}\right) .{ }^{4} \mathrm{PU} \cdot \mathrm{g}^{-1}$ (Phytase unit.gram ${ }^{-1}$ ).

After the enzymes analyses, Nile tilapia performance was assessed for 56 days. Tables 3 and 4 display the water quality and performance parameters, respectively.

There was a difference among treatments $(\mathrm{p}<0.05)$ for final weight, weight gain, feed conversion, and SGR. However, no differences were found for final weight and weight gain among the treatments with SSF inclusion after extrusion. Moreover, the addition of 800 ppm SSF before extrusion had no difference with that of $400 \mathrm{ppm}$ after extrusion. Therefore, the fish fed AE800 obtained $40.29 \%$ and $18.43 \%$ more weight gain ( $>$ $>0.05)$ compared with control and BE800, respectively.

Table 3. Water quality variables obtained during the experimental time.

\begin{tabular}{lcc}
\hline Parameters & Averages & CV (\%) \\
\hline $\mathrm{pH}$ & $6.56 \pm 0.17$ & 3.41 \\
Total ammonia $\left(\mathrm{mg} \cdot \mathrm{L}^{-1}\right)$ & $0.19 \pm 0.11$ & 7.93 \\
Temperature $\left({ }^{\circ} \mathrm{C}\right)$ & $27.05 \pm 1.34$ & 4.28 \\
Dissolved oxygen $(\mathrm{ppm})$ & $9.03 \pm 1.87$ & 3.01 \\
Conductivity $\left(\square \mathrm{Sm} . \mathrm{cm}^{-1}\right)$ & $40.90 \pm 9.90$ & 2.82 \\
\hline
\end{tabular}

For feed conversion, there were differences $(p>0.05)$ among the treatments. It is noteworthy that any of the diets supplemented with SSF presented an improved conversion, with AE800 being the most effective treatment.

SSF inclusion and extrusion processing also influenced SGR $(p<0.05)$, among which DE800 enhanced tilapia growth. Thus, feed conversion and
SGR results were better in the treatment DE800, being 31.96 and $22.22 \%$ higher compared to the control, respectively.

On the other hand, there was no effect $(p>0.05)$ of the SSF inclusion levels on final biomass, biomass gain, and survival rate. Likewise, the inclusion had no influence $(p>0.05)$ on Nile tilapia body composition (Table 5). 
M. G. MARTINS et al.

Table 4. Performance of Nile tilapia juveniles fed diets containing SSF enzyme complex added at different feed processing steps

\begin{tabular}{|c|c|c|c|c|c|c|}
\hline \multirow[t]{2}{*}{ Variables } & \multicolumn{5}{|c|}{ Treatments } & \multirow[t]{2}{*}{ CV $(\%)$} \\
\hline & Control & BE400 & $\mathrm{BE} 800$ & AE400 & AE800 & \\
\hline Initial weight(g) & 10.50 & 10.34 & 10.33 & 10.36 & 10.34 & 4.10 \\
\hline Final weight $(\mathrm{g})^{*}$ & $33.63 \mathrm{c}$ & $34.89 \mathrm{c}$ & $37.74 \mathrm{bc}$ & $39.61 \mathrm{ab}$ & $42.79 a$ & 5.58 \\
\hline Weight gain $(\mathrm{g}) *$ & $23.13 \mathrm{c}$ & $24.55 c$ & $27.40 \mathrm{bc}$ & $29.25 \mathrm{ab}$ & $32.45 \mathrm{a}$ & 8.18 \\
\hline Feed conversion $(\mathrm{g} / \mathrm{g}) *$ & $1.22 \mathrm{c}$ & $1.03 \mathrm{~b}$ & $1.01 \mathrm{~b}$ & $0.95 b$ & $0.83 \mathrm{a}$ & 4.44 \\
\hline Initial biomass (g) & 73.48 & 72.38 & 72.34 & 72.50 & 72.36 & 4.10 \\
\hline Final biomass (g) & 219.07 & 237.35 & 236.80 & 237.65 & 277.67 & 11.10 \\
\hline Biomass gain (g) & 150.75 & 170.09 & 169.66 & 175.51 & 210.36 & 14.06 \\
\hline Specific growth rate $(\%)$ & $2.07 b$ & $2.23 \mathrm{ab}$ & $2.22 \mathrm{ab}$ & $2.38 \mathrm{ab}$ & $2.53 \mathrm{a}$ & 4.95 \\
\hline Survivor $(\%)$ & 92.85 & 92.85 & 92.85 & 85.70 & 92.85 & 8.07 \\
\hline
\end{tabular}

*Means followed by different letters in the same line differ by Tukey test $(\mathrm{p}<0.05)$.

Table 5. Body composition of Nile tilapia juveniles fed diets containing SSF enzyme complex added at different feed processing steps.

\begin{tabular}{lrrrrr}
\hline \multirow{2}{*}{ Variables } & \multicolumn{4}{c}{ Treatments } \\
\cline { 2 - 6 } & Control & BE400 & BE800 & AE400 & AE800 \\
\hline Dry matter (\%) & 20.78 & 19.98 & 18.57 & 19.46 & 19.85 \\
Mineral matter (\%) & 13.26 & 13.73 & 13.46 & 12.53 & 12.63 \\
Total calcium (\%) & 3.53 & 3.83 & 3.63 & 3.25 & 3.22 \\
Crude fat (\%) & 13.33 & 13.51 & 13.35 & 13.28 & 13.27 \\
Crude protein (\%) & 56.68 & 55.84 & 56.07 & 56.28 & 55.50 \\
Total phosphorus (\%) & 2.03 & 2.49 & 2.17 & 2.14 & 2.11 \\
\hline
\end{tabular}

The heat in an extruder feed preparation promotes partial denaturation of the SSF enzyme complex. However, it can be added at higher levels to compensate for these losses. Yet, for improved responses, it should be added after extrusion since it provides a better animal performance and a lower amount and complexity of waste.

The b-glucosidase is a type of cellulase that acts in the final cellulose decomposition process by hydrolyzing cellobiose (AJWA; TABATABAI, 1994). We observed that b-glucosidase activity was partially reduced when subjected to extrusion. This result is similar to that found by Passos et al. (2008), who observed a reduction of b-glucosidase activity under high temperatures. Enzymes are proteins and therefore can be partially denatured by the high temperatures of an extrusion process.

Gomes et al. (2007) mentioned that pectinase and xylanase are key enzymes involved in cell wall degradation. Pectinase hydrolyzes pectin present in the middle lamella and primary wall of plant cells. Yet xylanase acts on xylan molecules by endogenous and exogenous mechanisms decomposing hemicellulose, which is one of the major components of plant cell walls. The same authors also pointed out that high temperature can cause total loss of pectinase and xylanase activities, as demonstrated in the enzyme activity assay developed in this study.

This enzymatic behavior also corroborates the findings of Uenojo and Pastore (2007), who emphasized a maximum pectinase activity at $50{ }^{\circ} \mathrm{C}$; they also stated that from this temperature the enzyme activity tends to reduce or stop, as observed here. When evaluating xylanases from different sources and their inclusion in wheat based diets, Reis et al. (2001) verified that a few types of xylanase have a peak activity at $75{ }^{\circ} \mathrm{C}$, others at $50{ }^{\circ} \mathrm{C}$, from these optimum temperatures on activity tends to decrease or be lost, as observed in this study.

Endoglucanase is responsible for starting the hydrolysis of cellulose and for random cleavage of internal glycosidic bonds of a cellulose chain (lignocellulose fiber), making them more exposed. Similarly to pectinase and xylanase, endoglucanase requires strict control of process temperature for preventing its denaturation (NELSON; COX, 2014). In this study, we observed a complete loss of endoglucanase activity due to the extrusion process conditions.

Amylase is a digestive enzyme of pancreatic origin which acts on polysaccharides in the chyme to enter the lumen of the duodenum (MOURA et al., 2007). In a study characterizing the corn-malt amylase activity, Biazus et al. (2006) noted a partial reduction of this enzyme activity at temperatures above $90{ }^{\circ} \mathrm{C}$, with an optimum point at $55^{\circ} \mathrm{C}$. These results corroborate those of the present study where amylase activity partly decreased due to the extrusion process.

Concerning protease, Giongo (2006) mentioned a wide variety of physiological functions performed by this enzyme, leading essential metabolic and regulatory functions through catalyzing protein degradation. This author also reported a partial loss of enzyme activity when it is subjected to temperature rise, confirming the results 
of this study.

The phytase acts on phytic acid in vegetable ingredients, the bioavailability of phosphorus and other minerals associated with this compound. (CHENG; HARDY, 2002). Studying phytase derived from sunflower seeds, Agostini and Ida (2006) verified no loss of phytase activity within a temperature range between 30 to $50{ }^{\circ} \mathrm{C}$. In another study, comparing some sources of the phytase of stemmed cereals, Esmaeilipour et al. (2012) observed that the enzyme stability becomes impaired at temperatures above $80{ }^{\circ} \mathrm{C}$, which is close to the extrusion temperature used in this trial.

For the performance trial, the recirculation system kept water quality within the same levels as observed by Kubitza (2000), who recommended a temperature range of $28-32{ }^{\circ} \mathrm{C}, \mathrm{pH}$ of $6.5-8.0$, total ammonia of $0-0.50 \mathrm{mg} . \mathrm{L}^{-1}$, conductivity of 23-71 $\mu \mathrm{Sm} . \mathrm{cm}^{-1}$, and dissolved oxygen of $>5.0$. These ranges were similar to those found in this study (Table 4), within which there was no interference with the animal growth.

Vieille and Zeikus (1996) emphasized that high temperatures can interference with the enzymatic activity of most of the exogenous enzymes, resulting in a reduced biological potency thereof. The same behavior was observed in this study with consequent impact on the final weight, weight gain, feed conversion, and specific growth rate.

Nevertheless, feed conversion was improved when the enzyme complex was added after extrusion (AE800), which indicates a partial loss of the product biological characteristics. This outcome can be proved by analyzing data from b-glucosidase and amylase activities, which partially lost their functionality, as well as through phytase activity data that showed no effect from extrusion process exposure.

Other experiments with enzyme supplementation for tilapia reinforce the idea of nutrient use improvements, resulting in a better animal performance (MOURA et al., 2007). In short, according to the literature, a reduction in production time and consequently in the final product cost (BELAL; KHALAFALLA, 2011; CAMPESTRINI; SILVA; APPET, 2005).

Analyzing the same fish species, Moura et al. (2007) observed that an addition of 150 ppm SSF into the diet improved animal weight gain as a function of an increasing bioavailability of nutrients, as observed in the present study. In another study, Belal and Khalafalla (2011) verified that Nile tilapia fingerlings fed diets with grasses and added with SSF replacing corn promoted improvements in growth and feed efficiency, as well as in the present study.

With respect to body composition, Signor et al. (2010) also observed no differences, except for ether extract, which had a linear decrease with the addition of enzyme complex (amylase, protease, cellulase, lipase, pectinase, xylanase, $\beta$-glucanase, and phytase) for Nile tilapia. In an experiment with microbial phytase, Oliva-Teles et al. (1998) observed no differences in the body composition of seabass juveniles (Dicentrarchus labrax).

Rocha et al. (2007), while studying different levels of enzyme supplementation (microbial phytase) for silver catfish fingerlings (Rhamdia quelem), found a similar body composition. These authors reported no significant difference in the following nutrients: dry matter, mineral matter, and crude protein. Silva et al. (2007), studying Nile tilapia juveniles under different levels of liquid phytase supplementation, found no statistical difference in calcium levels.

\section{CONCLUSION}

All the enzymes of SSF complex decrease or lose their catalytic activity if added before extrusion process, except for phytase. It has an impact on Nile tilapia performance, being $800 \mathrm{ppm}$ the best level to be added to the diet after extrusion process.

\section{AKNOWLEDGEMENTS}

To the Coordination for Higher Education Personnel Improvement (CAPES), to the National Council for Scientific and Technological Development $(\mathrm{CNPq})$ for granting scholarships, to the Research Support Foundation of the State of Minas Gerais (FAPEMIG), to the Brazilian Northeast Bank (BNB) for financial support, and to the Alltech Inc. for providing the enzyme complex Allzyme SSF.

\section{REFERENCES}

AGOSTINI, S. J.; IDA, E. I. Caracterização parcial e utilização da fitase extraída de sementes germinadas de girassol. Pesquisa agropecuária brasileira, Brasília, v. 41, n. 6, p. 1041-1047, 2006.

AJWA, H. A.; TABATABAI, M. A. Decomposition of different organic materials in soils. Biology and Fertility of Soils, Ames, v. 18, n. 3, p. 175-182, 1994.

AMERICAN PUBLIC HEALTH ASSOCIATION APHA. Standard methods for examination of water and wastewater. 22. ed. Washington: Water Environment Federation, 2012. 496 p.

BELAL, E. B.; KHALAFALLA, M. M. E. Biodegradation of Panicum repens residues by 
Pleurotus ostreatus for its use as a non-conventional feed stuff in diets of Oreochromis niloticus. African Journal of Microbiological Resarch, Lagos, v. 5, n. 19, p. 3038-3050, 2011.

BIAZUS, J. P. M. et al. Caracterização da atividade amilásica do malte de milho (Zea mays). Acta Scientiarum: Technology, Maringá, v. 28, n. 1, p. 13-19, 2006.

CAMPESTRINI, E.; SILVA, V. T. M.; APPET, M. D. Utilização de enzimas na alimentação animal. Revista Eletrônica Nutritime, Viçosa, v. 2, n. 6, p. 254-267, 2005.

CARAWAY, W. T. A stable starch substrate for the determination of amylase in serum and other body fluids. American Journal of Clinical Pathology, Oxford, v. 32, n. 1, p. 97-99, 1959.

CARLSON, D.; POULSEN, H. D. Phytate degradation in soaked and fermented liquid feedeffect of diet, time of soaking, heat treatment, phytase activity, $\mathrm{pH}$ and temperature. Animal Feed Science and Technology, Madrid, v. 103, n. 1-4, p. 141-154, 2003.

CHAUYNARONG, $\mathrm{N}$. et al. The influence of an exogenous microbial enzyme supplement on feed consumption, body growth and follicular development of pre-lay pullets on maise-soy diets. International Journal of Poultry Science, Champaign, v. 7, n. 3, p. 257-262, 2008.

CHENG, Z. J.; HARDY, R. W. Effect of microbial phytase on apparent nutrient digestibility of barley, canola meal, wheat and wheat middlings, measured in vivo using rainbow trout (Oncorhynchusmykiss). Aquaculture Nutrition, Porto, v. 8, n. 4, p. 271-277, 2002.

EL-SAYED, A. B. M. Tilapia culture. 1. ed. Alexandria: CABI, 2006. 277 p.

ESMAEILIPOUR, O. et al. Effects of temperature, $\mathrm{pH}$, incubation time and pepsin concentration on the in 475 vitro stability of intrinsic phytase of wheat barley and rye. Animal Feed Science and Technology, Madrid, v. 175, n. 3-4, p. 168-174, 2012.

GIONGO, J. L. Caracterização e aplicação de proteases produzidas por linhagens de Bacillus sp.. 2006. 95 f. Dissertação (Mestrado em Agroquímica: Área de concentração em Microbiologia Agrícola e do Meio-Ambiente) Universidade Federal do Rio Grande do Sul, Porto Alegre, 2006.

GOMES, E. et al. Enzimas termoestáveis: fontes, produção e aplicação industrial. Química Nova, São Paulo, v. 30, n. 1, p. 136-145, 2007.

JEGANNATHAN, K. R.; NIELSEN, P. H. Environmental assessment of enzyme use in industrial production - a literature review. Journal of Cleaner Production, Amsterdam, v. 42, n. 10, p. 228-240, 2013.

KUBITZA, F. Tilápia: tecnologia e planejamento na produção comercial. 1. ed. Jundiaí, SP: Edição do autor, 2000. 285 p.

MOURA, G. S. et al. Desempenho e atividade de amilase em tilápias-do-nilo submetidas a diferentes temperaturas. Pesquisa Agropecuária Brasileira, Brasília, v. 42, n. 11, p. 1609-1615, 2007.

MILLER, G. L. Use of dinitrosalicylic acid reagent for determination of reducing sugar. Analytical Chemistry, Washington, v. 31, n. 3, p. 426-428, 1956.

NELSON, D. L.; COX, M. Princípios de bioquímica de Lehninger. 6. ed. Porto Alegre, RS: ARTMED, 2014. 1328 p.

OLIVA-TELES, A. et al. Utilization of diets supplemented with microbial phytase by seabass (Dicentrarchus labrax) juveniles. Aquatic Living Resources, Cambridge, v. 11, n. 4, p. 255-259, 1998.

PASSOS, S. R. et al. Atividade enzimática e perfil da comunidade bacteriana em solo submetido à solarização e biofumigação. Pesquisa agropecuária brasileira, Brasília, v. 43, n. 7, p. 879-885, 2008.

REIS, T. A. F. C. et al. Avaliação do potencial biotecnológico de xilanases do Clostridum termo cellum e Cellvibriomixtus: sua utilização na suplementação de dietas à base de trigo para frango de corte. Revista Portuguesa de Ciências Veterinárias, Lisboa, v. 96, n. 539, p. 125-134, 2001.

ROCHA, B. C. et al. Suplementação de fitase microbiana na dieta de alevinos de jundiá: efeito sobre o desempenho produtivo e as características de carcaça. Ciência Rural, Santa Maria, v. 37, n. 6, p. 1772-1778, 2007.

SIGNOR, A. A. et al. Desempenho de juvenis de tilápia-do-nilo alimentados com rações contendo complexo enzimático. Revista Brasileira Zootecnia, Viçosa, v. 39, n. 5, p. 977-983, 2010.

SILVA, T. S. C. et al. Fitase líquida em dieta extrusada para juvenis de tilápia do Nilo (Oreochromis niloticus). Acta Sciencia Animal Sciences, Maringá, v. 29, n. 4, p. 449-455, 2007. 
TANIGUCHI, A. Y.; TAKANO, K. Purification and properties of B-galactosidase from tilapia intestine: Digestive enzyme to tilapia-X. Fisheries Science, Tokyo, v. 70, n. 4, p. 688-694, 2004.

UENOJO, M.; PASTORE, G. M. Pectinolytic enzymes. Industrial applications and future perspectives. Química Nova, São Paulo, v. 30, n. 2, p. 388-394, 2007.

VAN SOEST, P. J.; ROBERTSON, J. B.; LEWIS, B. A. Methods for dietary fiber, neutral detergent fiber, and non starch polysaccharides in relation to animal nutrition. Journal of Dairy Science, Champaign, v. 74, n. 10, p. 3583-3597, 1991.

VIEILLE, C.; ZEIKUS, J. Thermo enzymes: identifying molecular determinants of protein structural and functional stability. Trends in Biotechnology, Boston, v. 14, n. 1, p. 183-190, 1996. 